\title{
Photoelectrochemical Detection of Oxidative DNA Damage Induced by Fenton Reaction with Low Concentration and DNA-Associated $\mathrm{Fe}^{2+}$
}

\author{
Suping Jia, Minmin Liang, and Liang-Hong Guo* \\ State Key Laboratory of Environmental Chemistry and Ecotoxicology, Research Center for Eco-environmental \\ Sciences, Chinese Academy of Sciences, 18 Shuangqing Road, P.O. Box 2871, Beijing 100085, China
}

Received: December 6, 2007; In Final Form: January 26, 2008

\begin{abstract}
The metal ion dependent decomposition of hydrogen peroxide, the so-called Fenton Reaction, yields hydroxyl radicals that can cause oxidative DNA damage both in vitro and in vivo. We have previously reported a photoelectrochemical sensor for the detection of oxidative DNA damage induced by an $\mathrm{Fe}^{2+}$-mediated Fenton Reaction, using a DNA intercalator as a photoelectrochemical signal reporter (Liang, M.; Guo, L.-H. Environ. Sci. Technol. 2007, 41, 658). The intercalator binds less to the damaged DNA in the sensor film than the native form, resulting in a reduction in the measured photocurrent. In this report, some mechanistic aspects of the sensor were investigated. It was found that $\mathrm{Fe}^{2+}$ alone (without the coexistence of $\mathrm{H}_{2} \mathrm{O}_{2}$ ) suppressed the photocurrent of the intercalator bound to the DNA film in a pH-dependent manner. Similar $\mathrm{pH}$ dependence was observed for the $\zeta$ potential of the tin oxide nanoparticle colloid used in the preparation of the semiconductor electrode, leading to the hypothesis that the metal ion binds to the surface oxide groups on the electrode and quenches the photoelectrochemical response. At $\mathrm{pH} 3$, the quenching effect was reduced substantially to permit the detection of DNA damage by as low as $10 \mu \mathrm{M} \mathrm{Fe}^{2+}$ and $40 \mu \mathrm{M} \mathrm{H}_{2} \mathrm{O}_{2}$, a concentration that is within the physiologically relevant range. It was also found that $\mathrm{Fe}^{2+}$ ions associated with the DNA in the sensor film and participated in the DNA damage reaction, a mechanism that has been implicated in previous studies on metal carcinogenesis.
\end{abstract}

\section{Introduction}

Many metals are considered essential trace elements and must be present in low concentrations in the human body for normal cellular function. However, high concentrations of metals in the body are thought to be deleterious. Some transition metals have been confirmed to be human carcinogens or possibly carcinogenic to humans. ${ }^{1}$ A number of studies have shown that these metal ions induce their toxic effects primarily through their ability to produce reactive oxygen species. Iron is the most abundant transition metal in biological systems. $\mathrm{Fe}^{2+}$ has been found to react with $\mathrm{H}_{2} \mathrm{O}_{2}$ to produce the extremely reactive hydroxyl radical, the so-called Fenton Reaction. The radical can induce several classes of DNA damage, including single-strand break, double-strand break, abasic sites, and base oxidation. ${ }^{2}$

Association of iron with DNA has been implicated in a number of studies on DNA damage both in vivo and in vitro. Multiple-phase dose responses of DNA damage to $\mathrm{H}_{2} \mathrm{O}_{2}$ in the presence of $\mathrm{Fe}^{2+}$ were rationalized by the hypothesis of three types of $\mathrm{Fe}^{2+}$ participated in the Fenton reaction, ${ }^{3-6}$ i.e., the ions bound electrostatically to DNA, the ions bound to the DNA bases, and free $\mathrm{Fe}^{2+}$. Sequence-specific DNA cleavage by $\mathrm{Fe}^{2+}$ mediated Fenton reaction has been observed. ${ }^{7,8}$ Both computer modeling and NMR data support the postulation that the DNA sequence preference arise from the specific coordination geometry of the metal with the DNA bases. Binding of $\mathrm{Fe}^{2+}$ and $\mathrm{Fe}^{3+}$ with calf thymus DNA was investigated by FTIR and capillary electrophoresis. ${ }^{9}$ It was found that $\mathrm{Fe}^{2+}$ bound to DNA through guanine N-7 and the backbone phosphate with binding constants of $K_{\mathrm{G}}=5.4 \times 10^{4} \mathrm{M}^{-1}$ and $K_{\mathrm{P}}=2.4 \times 10^{4} \mathrm{M}^{-1}$.

* To whom correspondence should be addressed. Phone and Fax: (86)10-62849685. E-mail: LHGuo@rcees.ac.cn.
Given the fact that the hydroxyl radical is highly reactive and short-lived, it is very plausible that DNA damage is induced mainly by the radicals generated locally in the Fenton reaction between $\mathrm{H}_{2} \mathrm{O}_{2}$ and DNA-associated $\mathrm{Fe}^{2+}$, which are less prone to scavenging effect. However, there has been no direct experimental evidence to support such mechanism.

There are currently a number of cell-based assays as well as biochemical and chemical analytical techniques for the detection of DNA damage and the assessment of genetic toxicity. It is recommended that the genetic toxicity screening test should include three cell-based assays for gene mutation in bacteria, gene mutation in mammalian cells, and chromosomal aberration in mammalian cells, respectively. ${ }^{10}$ DNA damage products have been identified and quantified by a wide range of analytic techniques, such as single-cell gel electrophoresis, ${ }^{32} \mathrm{P}$-postlabeling, immunoassay, gas chromatography/mass spectrometry, high-performance liquid chromatography, and electrochemical and electrochemiluminescent sensors. ${ }^{11-16}$ We have developed a photoelectrochemical sensor for the detection of DNA damage by $\mathrm{Fe}^{2+}$ and styrene oxide. ${ }^{17}$ The sensor was assembled by depositing a layer of calf-thymus DNA on a tin oxide nanoparticle electrode. A DNA intercalator, $\mathrm{Ru}(\mathrm{bpy})_{2}(\mathrm{dppz})^{2+}$ (bpy $=2,2^{\prime}$-bipyridine, $\mathrm{dppz}=\operatorname{dipyrido}\left[3,2-a: 2^{\prime}, 3^{\prime}-c\right]$ phenazine $)$, was employed as the photoelectrochemical signal reporter. When the sensor was exposed to a solution containing $1 \mathrm{mM} \mathrm{Fe}^{2+}$ and $4 \mathrm{mM} \mathrm{H}_{2} \mathrm{O}_{2}$, the DNA on the sensor surface was damaged by the Fenton reaction, resulting in less binding with $\mathrm{Ru}(\mathrm{bpy})_{2^{-}}$ $(\mathrm{dppz})^{2+}$ and consequently lower signal than the native DNA (Scheme 1). However, the concentration of the two Fenton reagents was significantly higher than what would be encountered in vivo. In this report, some mechanistic aspects of the sensor were investigated in an effort to improve the sensitivity 
SCHEME 1: Illustration of Experimental Procedure: (1) Preparation of DNA Film Electrode, (2) DNA Damage Reaction, (3) Binding of Signal Molecule, and (4) Photocurrent Measurement

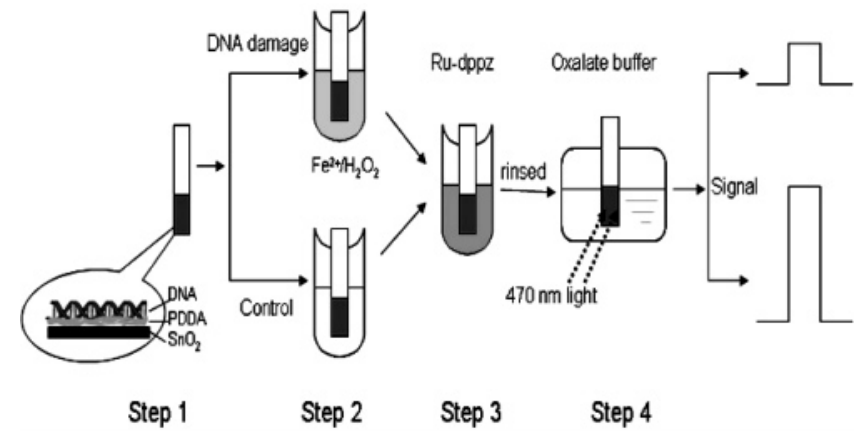

of the sensor. After optimization, the sensor was able to detect DNA damage induced by as low as $10 \mu \mathrm{M} \mathrm{Fe}^{2+}$ and $40 \mu \mathrm{M}$ $\mathrm{H}_{2} \mathrm{O}_{2}$. In addition, the sensor configuration provided a unique tool to investigate the role of DNA-bound $\mathrm{Fe}^{2+}$ in Fenton reaction and DNA damage. The results demonstrate explicitly that $\mathrm{Fe}^{2+}$ ions associated with DNA induced DNA damage in the presence of $\mathrm{H}_{2} \mathrm{O}_{2}$.

\section{Experimental Methods}

Poly-(diallydimethyl ammonium chloride) (PDDA) and double stranded calf thymus DNA (ds-DNA,13K base pairs) were from Sigma-Aldrich (St. Louis, MO). Iron sulfate heptahydrate was from Acros (Geel, Belgium). Fifteen percent tin(IV) oxide, as a colloidal dispersion of $15 \mathrm{~nm}$ particles, was obtained from Alfa Aesar (Ward Hill, MA), and so was hydrogen peroxide. All other chemicals and solvents were of analytical grade. Ru(bpy $)_{2}(\mathrm{dppz})\left(\mathrm{BF}_{4}\right)_{2}$ was synthesized according to the published procedure. ${ }^{18,19}$ Solutions were prepared in high-purity water from a Millipore Milli-Q (Biocel) water purification system. Tindoped indium oxide conductive glass was supplied by Weiguang Corp (Shenzhen, People's Republic of China).

Zeta potential of the $\mathrm{SnO}_{2}$ nanoparticle colloid was measured on a Zetasizer $2000 \zeta$ potential analyzer (Malvern Corp, United Kingdom). The purchased $\mathrm{SnO}_{2}$ colloid was diluted to $0.07 \%$ in water for the measurement. The $\mathrm{pH}$ of the colloid was adjusted with $\mathrm{HCl}$.

The preparation of $\mathrm{SnO}_{2}$ nanoparticle electrodes and the fabrication of the DNA films on the $\mathrm{SnO}_{2}$ electrode was the same as previously described. ${ }^{17,20}$ The concentrations of PDDA and DNA solution for film deposition were 2 and $0.5 \mathrm{mg} / \mathrm{mL}$, respectively. The DNA-modified electrode was denoted as $\mathrm{SnO}_{2} /$ PDDA/DNA. The DNA film on the electrode was damaged by exposing to $\mathrm{Fe}^{2+} / \mathrm{H}_{2} \mathrm{O}_{2}$ in water at $37{ }^{\circ} \mathrm{C}$ with vortex (200rpm) for $1 \mathrm{~h}$ or for a time period as specified.

The photocurrent was measured on a CHI 630A electrochemical analyzer ( $\mathrm{CH}$ Instruments, Austin, TX) using a Pt flag counter electrode, a $\mathrm{Ag} / \mathrm{AgCl}(3 \mathrm{M} \mathrm{KCl})$ reference electrode, and a bias voltage of $+0.1 \mathrm{~V}$. The excitation light source was a blue light emitting diode (Lamp Inc., Shenzhen, People's Republic of China) with an illumination area of $0.2 \mathrm{~cm}^{2}$. A DNA film electrode with either intact or damaged DNA was first reacted with $50 \mu \mathrm{M} \mathrm{Ru}(\mathrm{bpy})_{2}(\mathrm{dppz})^{2+}$ for $30 \mathrm{~min}$ in order for the signal reporter to bind to the DNA film. After the reaction, the unbound metal complex was washed off by water. Photocurrent was then measured by placing the electrode in $30 \mathrm{mM}$ oxalate buffer, $\mathrm{pH} 5.8$.
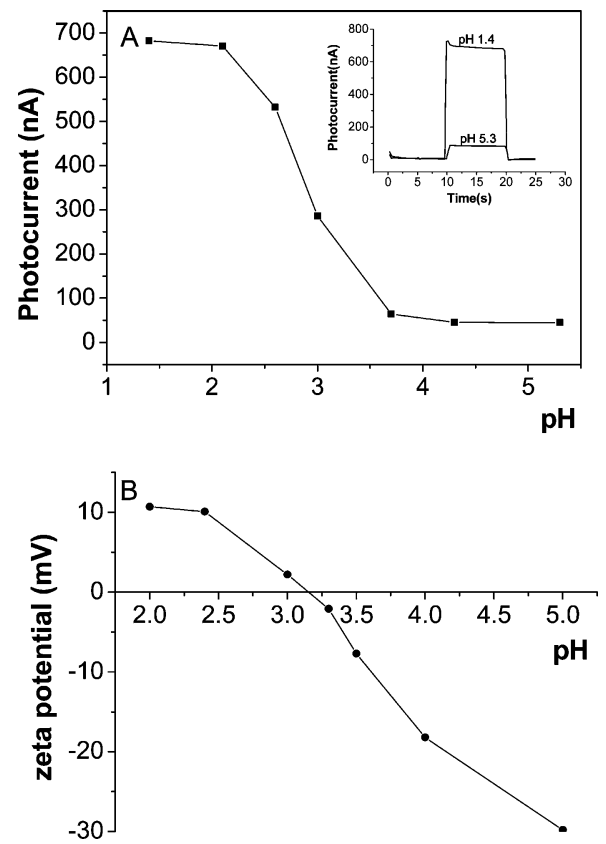

Figure 1. (A) Plot of anodic photocurrent of $\mathrm{Ru}(\mathrm{bpy})_{2}(\mathrm{dppz})^{2+}$ bound to $\mathrm{SnO}_{2} / \mathrm{PDDA} / \mathrm{DNA}$ electrode after the DNA film was exposed to 1 $\mathrm{mM} \mathrm{Fe}{ }^{2+}$ at different $\mathrm{pH}$ values. Inset is typical photocurrent response curve. (B) $\zeta$ potential of $15 \mathrm{~nm}$ tin oxide colloid diluted in water as a function of $\mathrm{pH}$.

\section{Results and Discussion}

As already described in the introduction, the photoelectrochemical sensor we reported before was able to detect DNA damage in $1 \mathrm{mM} \mathrm{Fe}{ }^{2+} / 4 \mathrm{mM} \mathrm{H}_{2} \mathrm{O}_{2}$ Fenton reagents. The photocurrent of $\mathrm{Ru}(\mathrm{bpy})_{2}(\mathrm{dppz})^{2+}$ bound to the damaged DNA film was reduced remarkably as compared with the native DNA. To make the detection relevant to the in vivo situation, the concentration of the two reagents must be lowered to low micromolarity, which is the typical concentration inside living cells. $^{21,22}$ In the process of improving the sensor sensitivity, it was found that exposure of the DNA electrode to the metal ion alone (without $\mathrm{H}_{2} \mathrm{O}_{2}$ ) suppressed the measured photocurrent in a pH-dependent manner (Figure 1a). The photocurrent was reduced to background after the $\mathrm{SnO}_{2} / \mathrm{PDDA} / \mathrm{DNA}$ electrode was exposed to $1 \mathrm{mM} \mathrm{Fe}^{2+}$ at $\mathrm{pH} 4.0$ or higher, while at $\mathrm{pH}$ below 2.0 the signal did not change significantly as compared with the nonexposed electrode. Since photocurrent was measured in an oxalate solution after the DNA electrode was exposed to $\mathrm{Fe}^{2+}$ and rinsed, the detrimental effect must be caused by the metal ions adsorbed on the sensor surface. In a control experiment, a bare $\mathrm{SnO}_{2}$ electrode was first exposed to $1 \mathrm{mM}$ $\mathrm{Fe}^{2+}$ at $\mathrm{pH} 5.3$, followed by the assembly of DNA film, binding of $\mathrm{Ru}(\mathrm{bpy})_{2}(\mathrm{dppz})^{2+}$, and photocurrent measurement. Signal reduction was also observed, suggesting the detrimental effect arose from the $\mathrm{Fe}^{2+}$ ions adsorbed directly on the semiconductor surface. In the study of photodegradation of organic dyes by $\mathrm{TiO}_{2}$ nanoparticles under visible irradiation, it was found that some transition metal ions such as $\mathrm{Cu}^{2+}$ and $\mathrm{Fe}^{3+}$ having suitable redox potentials altered the photoinduced electron-transfer pathway and markedly depressed the dye degradation efficiency. ${ }^{23}$ The reduction potential of $\mathrm{Fe}^{3+} / \mathrm{Fe}^{2+}, \mathrm{Ru}^{3+} / \mathrm{Ru}^{2+}$, and $\mathrm{Ru}^{3+} / \mathrm{Ru}^{2+*}$ is $0.77,1.62$, and $-0.38 \mathrm{~V}$ vs normal hydrogen electrode, respectively. ${ }^{24}$ At $\mathrm{pH} \mathrm{3,} \mathrm{the} \mathrm{reduction} \mathrm{potential} \mathrm{of}$ the conduction band and valence band of $\mathrm{SnO}_{2}$ nanoparticle is 0.3 and $3.9 \mathrm{~V}$, respectively. ${ }^{25}$ According to the illustration shown in Scheme 2, it can be speculated that in our work the $\mathrm{Fe}^{2+}$ ions adsorbed on the $\mathrm{SnO}_{2}$ surface can scavenge the photoex- 
SCHEME 2: Illustration of Possible Quenching Mechanism of $R u(b p y)_{2}(d p p z)^{2+}$ Photocurrent by Surface-Adsorbed $\mathrm{Fe}^{2+}$ (Potentials Are Not Drawn to Scale)

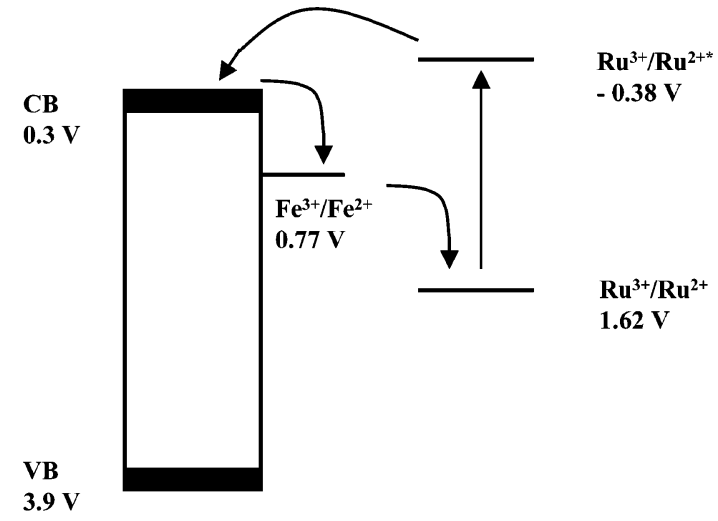

cited electrons of the ruthenium complex and reduce its photocurrent.

The observed $\mathrm{pH}$ dependence suggests there are some charged groups on the $\mathrm{SnO}_{2}$ surface that are involved in the interaction with $\mathrm{Fe}^{2+}$. To investigate the issue further, the $\zeta$ potential of the $\mathrm{SnO}_{2}$ nanoparticle colloid used for the fabrication of the electrode was measured at various $\mathrm{pH}$ solutions. As shown in Figure $1 \mathrm{~b}$, the $\zeta$ potential displays a $\mathrm{pH}$ dependence very similar to the one observed in the photocurrent measurement. From the graph, the PZC (point of zero charge) of $\mathrm{SnO}_{2}$ is estimated to be $\mathrm{pH} 3.2$, which is slightly lower than the value of $\mathrm{pH} 4.0$ reported in the literature. ${ }^{26}$ The discrepancy may be caused by the presence of some dispersing agents in the colloid we purchased. At $\mathrm{pH}$ above 3.2 , the $\zeta$ potential is negative. It is well known that there exist hydroxyl groups on the surface of many metal oxides that may interact with metal ions by either electrostatic attraction or coordination. The strong correlation of $\mathrm{pH}$ dependence between photocurrent, $\zeta$ potential, as well as the PZC value supports the notion that $\mathrm{Fe}^{2+}$ ions can adsorb on $\mathrm{SnO}_{2}$ electrode through its surface hydroxyl groups.

Although the adsorption of $1 \mathrm{mM} \mathrm{Fe}^{2+}$ on the semiconductor surface was eliminated at $\mathrm{pH}$ below 2.0, its Fenton reaction with $\mathrm{H}_{2} \mathrm{O}_{2}$ was also prohibited at these low $\mathrm{pH}$ values, as evident from the loss of change in photocurrent after the $\mathrm{SnO}_{2} / \mathrm{PDDA} /$ DNA sensor was exposed to the Fenton reagents. As a compromise, $\mathrm{pH} 3.0$ was selected. At this $\mathrm{pH}$, the deleterious effect of $\mathrm{Fe}^{2+}$ on photocurrent was completely eliminated as long as its concentration was kept at $100 \mu \mathrm{M}$ or less, and the Fenton reaction could still proceed well (Figure 2). In addition, reduction in photocurrent of the damaged DNA film in the sensor decreased as the concentration of the two Fenton reagents $\left(\mathrm{Fe}^{2+}\right.$ and $\left.\mathrm{H}_{2} \mathrm{O}_{2}\right)$ was lowered. The lowest concentration the photoelectrochemical sensor detected was $10 \mu \mathrm{M} \mathrm{Fe}^{2+} / 40 \mu \mathrm{M}$ $\mathrm{H}_{2} \mathrm{O}_{2}$. The metal ion and $\mathrm{H}_{2} \mathrm{O}_{2}$ did not show such effect individually, indicating that the observed drop in photocurrent was induced by the Fenton reaction between the two reagents. It has been reported that the concentration of $\mathrm{Fe}^{2+}$ inside living cells is in the low micromolar range..$^{21,22}$ Therefore, the photoelectrochemical DNA sensor is now capable of detecting DNA damage at physiologically relevant concentrations.

As mentioned in the Introduction, association of iron with DNA and its participation in Fenton reaction and DNA damage has been implicated in a number of studies. ${ }^{3-8}$ However, there has been no direct experimental evidence to support such hypothesis. The surface reaction mode in our photoelectrochemical sensor provided a unique opportunity to investigate

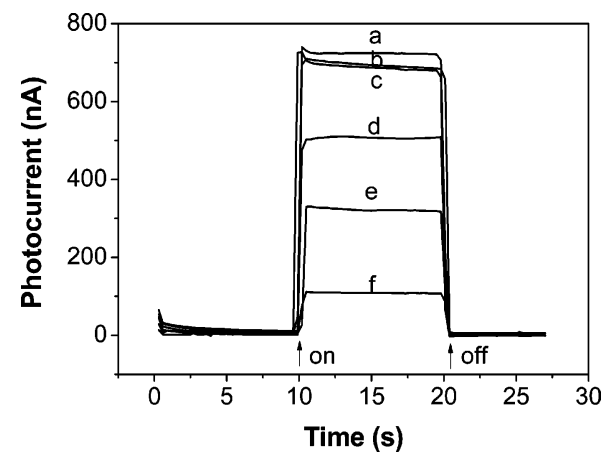

Figure 2. Anodic photocurrent response of $\mathrm{Ru}(\mathrm{bpy})_{2}(\mathrm{dppz})^{2+}$ bound to $\mathrm{SnO}_{2} / \mathrm{PDDA} / \mathrm{DNA}$ electrodes after the DNA film was exposed to (a) water, (b) $400 \mu \mathrm{M} \mathrm{H}_{2} \mathrm{O}_{2}$, (c) $100 \mu \mathrm{M} \mathrm{FeSO}$, pH 3.0, (d) $10 \mu \mathrm{M}$ $\mathrm{FeSO}_{4} / 40 \mu \mathrm{M} \mathrm{H}_{2} \mathrm{O}_{2}$, pH 3.0, (e) $20 \mu \mathrm{M} \mathrm{FeSO}_{4} / 80 \mu \mathrm{M} \mathrm{H}_{2} \mathrm{O}_{2}$, pH 3.0, and (f) $100 \mu \mathrm{M} \mathrm{FeSO}_{4} / 400 \mu \mathrm{M} \mathrm{H}_{2} \mathrm{O}_{2}, \mathrm{pH}$ 3.0. Excitation light was switched on and off as indicated.

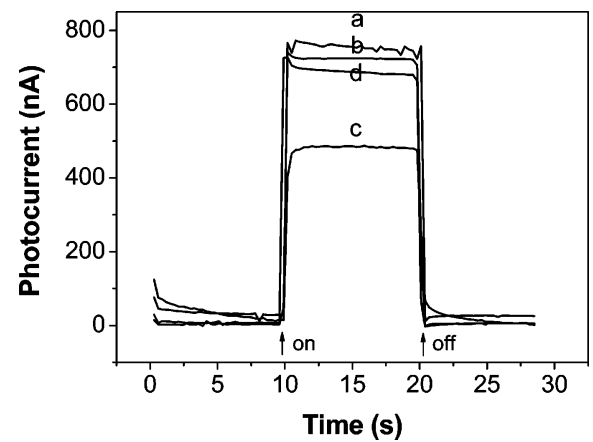

Figure 3. Anodic photocurrent response of $\mathrm{Ru}(\mathrm{bpy})_{2}(\mathrm{dppz})^{2+}$ bound to $\mathrm{SnO}_{2} / \mathrm{PDDA} / \mathrm{ds}-\mathrm{DNA}$ electrode after the DNA film was exposed to (a) water for $2 \mathrm{~h}$, (b) $400 \mu \mathrm{M} \mathrm{H}_{2} \mathrm{O}_{2}$ for $2 \mathrm{~h}$, (c) $100 \mu \mathrm{M} \mathrm{Fe}^{2+}$ for $1 \mathrm{~h}$, water rinse, then $400 \mu \mathrm{M} \mathrm{H}_{2} \mathrm{O}_{2}$ for $1 \mathrm{~h}$, (d) $100 \mu \mathrm{M} \mathrm{Fe}^{2+}$ for $1 \mathrm{~h}, 5$ mM EDTA rinse, then $400 \mu \mathrm{M} \mathrm{H}_{2} \mathrm{O}_{2}$ for $1 \mathrm{~h}$. Excitation light was switched on and off as indicated.

the role of DNA-associated metals in the Fenton reaction. In the experiment, the $\mathrm{SnO}_{2} / \mathrm{PDDA} / \mathrm{DNA}$ sensor was assembled as usual and then exposed to $100 \mu \mathrm{M} \mathrm{Fe}^{2+}$. After rinse with water, the sensor was reacted with $400 \mu \mathrm{M} \mathrm{H}_{2} \mathrm{O}_{2}$. Finally, the DNA film was allowed to bind to $\mathrm{Ru}(\mathrm{bpy})_{2}(\mathrm{dppz})^{2+}$, and its photocurrent was measured. As can be seen in Figure 3, the measured signal was reduced by one-third as compared with the blank control (water only) and $\mathrm{H}_{2} \mathrm{O}_{2}$ control $\left(\mathrm{H}_{2} \mathrm{O}_{2}\right.$ only). Since the sensor was rinsed after $\mathrm{Fe}^{2+}$ exposure, the result suggests the metal bound to the sensor film and participated in the Fenton reaction during the subsequent exposure to $\mathrm{H}_{2} \mathrm{O}_{2}$. In another experiment, the sensor was incubated in an EDTA solution immediately after its reaction with $\mathrm{Fe}^{2+}$, followed by the same treatment with $\mathrm{H}_{2} \mathrm{O}_{2}$ and $\mathrm{Ru}(\mathrm{bpy})_{2}(\mathrm{dppz})^{2+}$. The photocurrent was essentially the same as the blank control. EDTA is a very strong chelator for $\mathrm{Fe}^{2+}$. Apparently, the chelator had removed the metal ion from the sensor film and thus eliminated the subsequent Fenton reaction with $\mathrm{H}_{2} \mathrm{O}_{2}$.

In a further experiment, the location of $\mathrm{Fe}^{2+}$ bound to the sensor film was investigated. As described in the Experimental section, the sensor film was fabricated by layer-by-layer assembly of PDDA and DNA on a tin oxide electrode. The sensor was exposed to $100 \mu \mathrm{M} \mathrm{Fe}^{2+}$ at different stages during the film assembly process, as illustrated below. The arrow sign indicates the stage where the sensor was exposed to the metal ion. After DNA was deposited on the electrode, the sensor was incubated in $\mathrm{H}_{2} \mathrm{O}_{2}$ and then $\mathrm{Ru}(\mathrm{bpy})_{2}(\mathrm{dppz})^{2+}$. As shown in Figure 4, exposure of either $\mathrm{SnO}_{2}$ or $\mathrm{SnO}_{2} / \mathrm{PDDA}$ to a solution of $100 \mu \mathrm{M} \mathrm{Fe}^{2+}$ did not induce any change in photocurrent. 


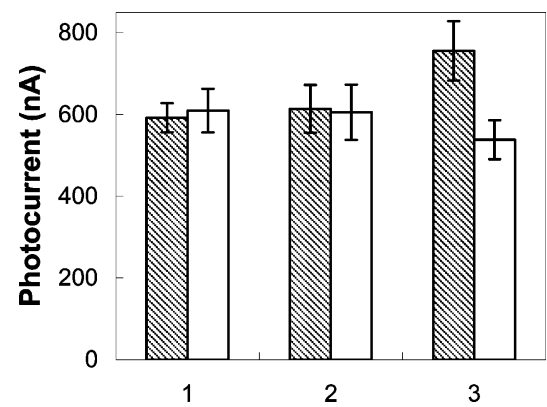

Figure 4. Photocurrent of $\mathrm{Ru}(\mathrm{bpy})_{2}(\mathrm{dppz})^{2+}$ bound to the $\mathrm{SnO}_{2} / \mathrm{PDDA} /$ DNA electrode after the film was exposed to $100 \mu \mathrm{M} \mathrm{Fe}^{2+}, \mathrm{pH} 3.0$ (filled column), or exposed first to $100 \mu \mathrm{M} \mathrm{FeSO}_{4}, \mathrm{pH} 3.0$, then to $400 \mu \mathrm{M} \mathrm{H}_{2} \mathrm{O}_{2}$ after the DNA layer was deposited (empty column). The electrode was exposed to $\mathrm{Fe}^{2+}$ at different stages during the film assembly process. (1) $\mathrm{Bare} \mathrm{SnO}_{2}$ exposed to $\mathrm{Fe}^{2+}$, (2) $\mathrm{SnO}_{2} / \mathrm{PDDA}$ exposed to $\mathrm{Fe}^{2+}$, (3) $\mathrm{SnO}_{2}$ /PDDA/DNA exposed to $\mathrm{Fe}^{2+}$.

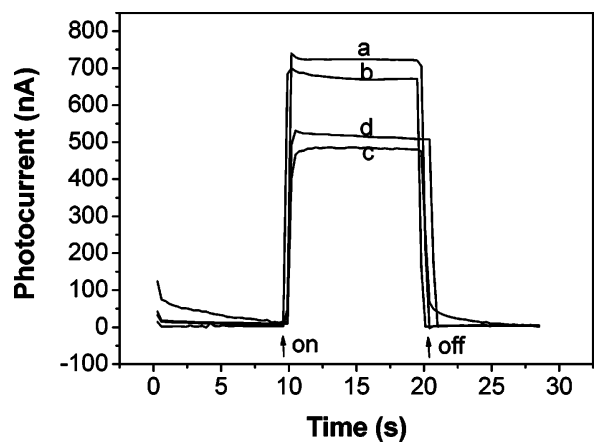

Figure 5. Anodic photocurrent response of $\mathrm{Ru}(\mathrm{bpy})_{2}(\mathrm{dppz})^{2+}$ bound to $\mathrm{SnO}_{2} / \mathrm{PDDA} / \mathrm{ds}-\mathrm{DNA}$ electrode after the DNA film was exposed to $100 \mu \mathrm{M} \mathrm{Fe}^{2+}$ for $1 \mathrm{~h}$, water rinse and then in (a) $0 \mu \mathrm{M}$, (b) $40 \mu \mathrm{M}$, (c) $400 \mu \mathrm{M}$, and (d) $4 \mathrm{mM} \mathrm{H}_{2} \mathrm{O}_{2}$ for $1 \mathrm{~h}$. Excitation light was switched on and off as indicated.

However, as already described above, when the DNA modified electrode $\left(\mathrm{SnO}_{2} / \mathrm{PDDA} / \mathrm{DNA}\right)$ was reacted with the metal ion first and then reacted with $\mathrm{H}_{2} \mathrm{O}_{2}$, the signal dropped substantially. The combined data in Figures 3 and 4 revealed very clearly that $\mathrm{Fe}^{2+}$ ions were associated with the DNA molecules in the sensor film and engaged in the Fenton reaction and DNA damage.

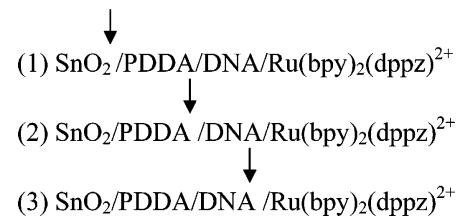

A solution of $10 \mu \mathrm{M} \mathrm{Fe}^{2+}$ did not produce detectable signal change after its association with DNA film. Therefore, adsorption isotherm with DNA is not available.

The dependence of photocurrent on $\mathrm{H}_{2} \mathrm{O}_{2}$ concentration was examined and is shown in Figure 5. It seems there is an optimal $\mathrm{H}_{2} \mathrm{O}_{2}$ concentration for DNA-associated $\mathrm{Fe}^{2+}$ adsorbed from $100 \mu \mathrm{M}$ solution.

\section{Conclusions}

In conclusion, the previously developed photoelectrochemical sensor for $\mathrm{Fe}^{2+}$-mediated oxidative DNA damage was investi- gated in details. It was found that $\mathrm{Fe}^{2+}$ alone suppressed the measured photocurrent signal in a $\mathrm{pH}$-dependent manner. On the basis of the $\zeta$ potential measurement of the tin oxide nanoparticle colloid, the detrimental effect was attributed to the adsorption of the metal ion on the semiconductor surface and its quenching effect on the photoexcited signaling molecule. At $\mathrm{pH} 3$, the deleterious effect was reduced substantially to permit the detection of DNA damage by as low as $10 \mu \mathrm{M} \mathrm{Fe}^{2+}$ and $40 \mu \mathrm{M} \mathrm{H}_{2} \mathrm{O}_{2}$, a concentration that is within the physiologically relevant range. Taking the advantage of the surface reaction mode of the sensor, $\mathrm{Fe}^{2+}$ association with DNA in the sensor film and its participation in the subsequent Fenton reaction with $\mathrm{H}_{2} \mathrm{O}_{2}$ and DNA damage was demonstrated explicitly, a mechanism that has been implicated in previous studies on metal carcinogenesis.

Acknowledgment. This work was supported by the National Hi-Tech Research and Development Program of China (2006AA06Z422) and the National Natural Science Foundation of China (20675087, 20621703).

\section{References and Notes}

(1) Richard, B. H. Cancer Cause. Control 1997, 8, 371.

(2) Valko, M.; Morris, H.; Cronin, M. T. D. Curr. Med. Chem. 2005, 12,1161 .

(3) Imlay, J. A.; Chin, S. M.; Linn, S. Science 1988, 240, 640.

(4) Luo, Y.; Han, Z. X.; Chin, M.; Linn, S. Proc. Natl. Acad. Sci. U.S.A. 1994, 91, 12438 229.

(5) Kaneko, M.; Kodama, M.; Inoue, F. Free Radical Res. 1994, 20,

(6) Bertoncini, C. R. A.; Meneghini, R. Nucleic Acids Res. 1995, 23 2995.

(7) Henle, E. S.; Han, Z.; Tang, N.; Rai, P.; Luo, Y. R. H.; Linn, S. J. Biol. Chem. 1999, 274, 962.

(8) Priyamvada, R.; Wemmer, D. E.; Linn, S. Nucleic Acids Res. 2005, 33,497 .

(9) Ouameur, A. A.; Arakawa, H.; Ahmad, R.; Naoui, M.; Tajmitriahi, H. A. DNA Cell Boil. 2005, 24, 394.

(10) Eisenbrand, G.; Pool-Zobel, B.; Baker, V.; Balls, M.; Blaauboer, B. J.; Boobis, A.; Carere, A.; Kevekordes, S.; Lhuguenot, J. C.; Pieters, R.; Kleiner, J. Food Chem. Toxicol. 2002, 40, 193.

(11) Pfeifer, G. P. Technologies for Detection of DNA Damage and Mutations; Plenum: New York, 1996.

(12) Thorp, H. H. Top. Curr. Chem. 2004, 237, 159

(13) Rusling, J. F. Biosens. Bioelectron. 2004, 20, 1022

(14) Cahova-Kucharikova, K.; Fojta, M.; Mozga, T.; Palecek, E. Anal. Chem. 2005, 77, 2920.

(15) Palecek, E.; Fojta, M.; Tomschik, M.; Wang, J. Biosens. Bioelectron. 1998, 13, 621

(16) Liu, J.; Roussel, C.; Lagger, G.; Tacchini, P.; Girault, H. H. Anal. Chem. 2005, 77, 7687.

(17) Liang, M.; Guo, L.-H. Environ. Sci. Technol. 2007, 41, 658.

(18) Musumeci, S.; Rizzarelli, F. S.; Sammartano, S.; Bonomo, R. P. Inorg. Chim. Acta 1973, 7, 660.

(19) Edmond, A.; Abdulrazzak, H. J. Chem. Soc., Dalton Trans. 1990 1841.

(20) Liang, M.; Liu, S. L.; Wei, M.-Y.; Guo, L.-H. Anal. Chem. 2006, 78,621 .

(21) Epsztein, S.; Kakhlon, O.; Glickstein, H.; Breuer, W.; Cabantchik, Z. I. Anal. Biochem. 1997, 248, 31.

(22) Keyer, K.; Imlay, J. A. Proc. Natl. Acad. Sci., U.S.A. 1996, 93 13635

(23) Chen, C. C.; Li, X. Z.; Ma, W. H.; Zhao, J. C. J. Phys. Chem. B 2002, 106, 318

(24) Murphy, C. J.; Arkin, M. R.; Ghatlia, N. D.; Bossmann, S.; Turro, N. J.; Barton, J. K. Proc. Natl. Acad. Sci. 1994, 91, 5315.

(25) Kalyanasundaram, K.; Gratzel, M. Coord. Chem. Rev. 1998, 177, 347.

(26) Ionita, M.; Cappelletti, G.; Minguzzi, A.; Ardizzone, S.; Bianchi, C.; Rondinini, S.; Vertova, A. J. Nanopart. Res. 2006, 8, 653. 